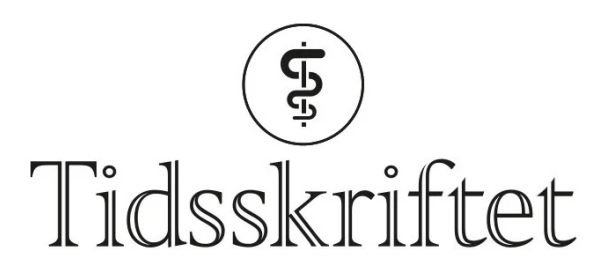

DEN NORSKE LEGEFORENING

\title{
En ung kvinne som ikke våknet etter omfattende operasjon
}

NOE Å LARE AV

\section{INGRID KNUTSDOTTER FOSHEIM}

Medisinsk fakultet

Universitetet i Oslo

Ingrid Knutsdotter Fosheim er medisinstudent og forskerlinjestudent.

Forfatteren har fylt ut ICMJE-skjemaet og oppgir ingen interessekonflikter.

\section{KARINA ROHEIM LAPPEN}

\section{Akuttklinikken}

Oslo universitetssykehus, Rikshospitalet

Karina Roheim Lappen er spesialist i anestesiologi og er overlege.

Forfatteren har fylt ut ICMJE-skjemaet og oppgir ingen interessekonflikter.

\section{KRISTIAN HELDAL}

Seksjon for nyremedisin Avdeling for transplantasjonsmedisin Oslo universitetssykehus, Rikshospitalet Kristian Heldal er spesialist i indremedisin og i nyresykdommer og er overlege. Forfatteren har fylt ut ICMJE-skjemaet og oppgir ingen interessekonflikter.

\section{ANTHONY BURTON MARIATHASAN}

Avdeling for gastro- og barnekirurgi

Oslo universitetssykehus, Radiumhospitalet

Anthony Burton Mariathasan er spesialist i generell kirurgi og i gastroenterologisk kirurgi og er overlege.

Forfatteren har fylt ut ICMJE-skjemaet og oppgir ingen interessekonflikter.

\section{KRISTOFFER KOPSTAD LUNDESGAARD}

Avdeling for radiologi Oslo universitetssykehus, Rikshospitalet

Kristoffer Kopstad Lundesgaard er spesialist i radiologi og er overlege. Forfatteren har fylt ut ICMJE-skjemaet og oppgir ingen interessekonflikter.

\section{BJØRN PETTER BENTERUD}

Akuttklinikken

Oslo universitetssykehus, Rikshospitalet

Bjørn Petter Benterud er spesialist i anestesiologi og overlege ved Avdeling for anestesiologi, Oslo universitetssykehus.

Forfatteren har fylt ut ICMJE-skjemaet og oppgir ingen interessekonflikter. 
Regional kompetansetjeneste for import- og tropesykdommer

Avdeling for infeksjonsmedisin

Oslo universitetssykehus, Ullevål

Frank Olav Pettersen er ph.d., spesialist i infeksjonssykdommer og i medisinsk mikrobiologi, overlege og enhetsleder.

Forfatteren har fylt ut ICMJE-skjemaet og oppgir ingen interessekonflikter.

\section{KNUT JØRGEN LABORI}

Avdeling for gastro- og barnekirurgi

Oslo universitetssykehus, Rikshospitalet

og

Institutt for klinisk medisin

Universitetet i Oslo

Knut Jørgen Labori er dr.med., spesialist i generell kirurgi og i gastroenterologisk kirurgi, overlege og professor.

Forfatteren har fylt ut ICMJE-skjemaet og oppgir ingen interessekonflikter.

\section{SHERAZ YAQUB}

sheraz.yaqub@ous-hf.no

Avdeling for gastro- og barnekirurgi

Oslo universitetssykehus, Rikshospitalet

og

Institutt for klinisk medisin

Universitetet i Oslo

Sheraz Yaqub er dr.med., FEBS og spesialist i generell kirurgi og i gastroenterologisk kirurgi, overlege og førsteamanuensis.

Forfatteren har fylt ut ICMJE-skjemaet og oppgir ingen interessekonflikter.

\section{En kvinne i 30-årene gjennomgikk en langvarig operasjon for parasittære cyster i lever og bukhule. På grunn av intraoperativ cysteruptur ble bukhulen skylt med hypertont saltvann på slutten av inngrepet. Pasienten våknet ikke etter ekstubering og var sirkulatorisk ustabil. Det videre forløpet ble alvorlig og var potensielt dødelig.}

En kvinne i 30 -årene hadde noen år tidligere fått påvist en solitcer levercyste i forbindelse med utredning for magesmerter. Cysten ble behandlet med perkutan drenasje og sklerosering. Grunnet raskt residiv ble det utført kikkhullskirurgi med delvis fjerning av cysteveggen (laparoskopisk fenestrering) tre måneder senere. Cysteveggen ble sendt til histopatologisk unders $\emptyset$ kelse, som ikke viste patologi $i$ veggen eller parasittsykdom. Fra tidligere hadde pasienten diabetes mellitus type 1 og ulcerøs kolitt. Blodsukkeret var velregulert med insulinpumpe. To år etter fjerning av cysteveggen var hun fortsatt plaget med magesmerter. CT viste tallrike cyster i leveren og bukhulen fra diafragma til bekkenbunn (figur 1). Mistanken om parasittinfeksjon ble reist på nytt, og regranskning av cysteveggen fra operasjon to år tidligere var forenlig med dette. Serologisk prøve bekreftet infeksjon med parasitten Echinococcus granulosus. 


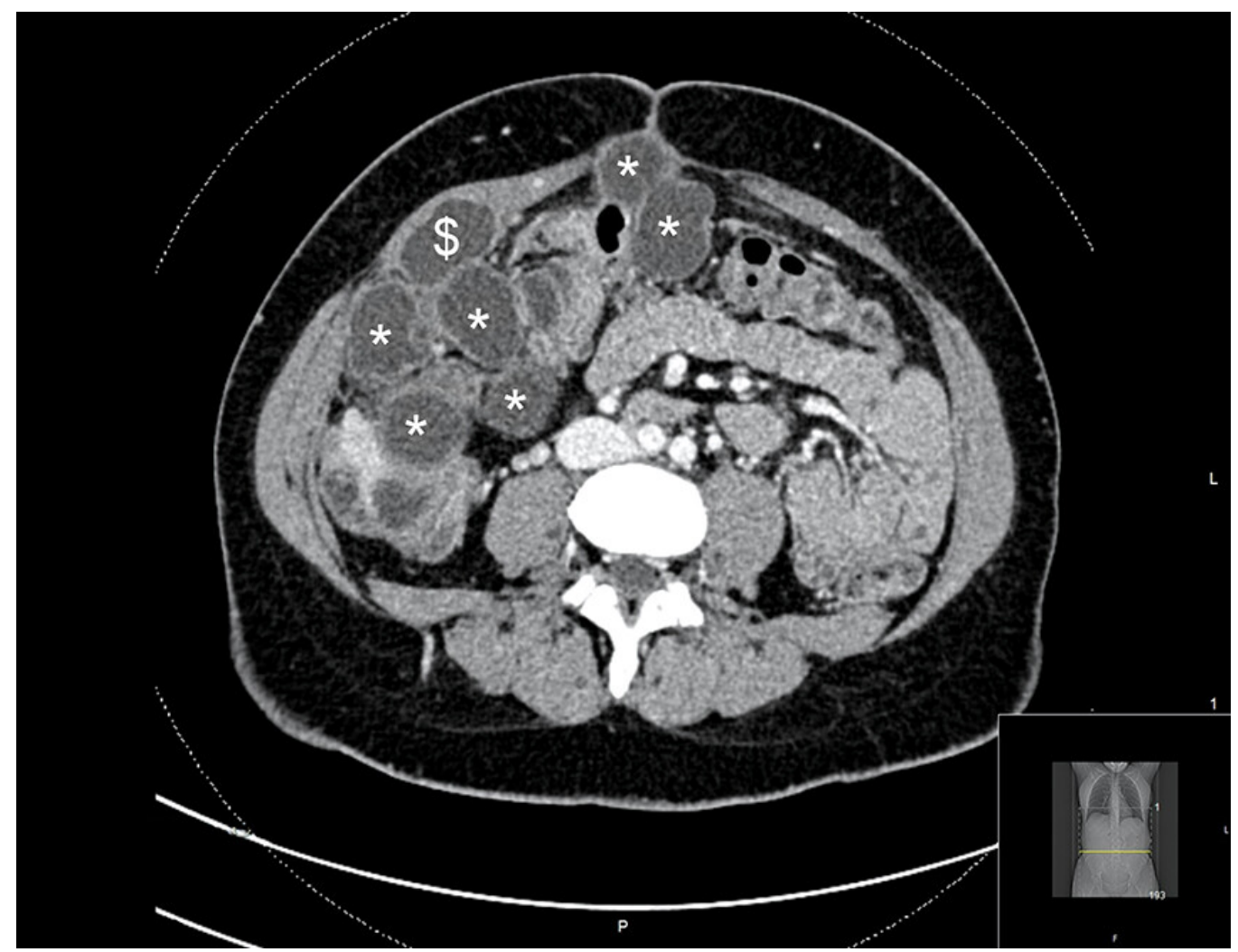

Figur 1 CT abdomen med kontrast, aksialplan. Man ser multiple cyster i fascie og intraabdominalt $\left({ }^{*}\right)$ samt cyste i $\mathrm{m}$. rectus abdominis $(\$)$.

Hundens dvergbendelmark, E. granulosus, kan danne cyster i ulike organer, såkalt cystisk ekinokokkose, som hyppigst forekommer i leveren (1). Inkubasjonstiden er lang, ofte flere år. Cystene gir etter hvert magesmerter og kan presse på naboorganer. Ekinokokker smitter fekalt-oralt fra hovedvert, som er hundedyr, til mellomverter som gressetende husdyr (typisk sau) eller til mennesker som aksidentell mellomvert. Cystisk ekinokokksykdom overføres ikke fekal-oralt mellom mennesker (므).

Smittekilden var i dette tilfellet uavklart. Da laparoskopisk fenestrering av cysten ble utført, var serologisk testing for E. granulosus ikke tilgjengelig i Norge, og prøver måtte sendes til Sverige eller Danmark. Pasienten var etnisk norsk og uten relevant reiseanamnese, og cysten hadde utseende som en simpel cyste. Da man på denne bakgrunn vurderte at pasienten hadde lav sannsynlighet for smitte med ekinokokksykdom, ble det ikke utført serologisk testing for $\mathrm{E}$. granulosus.

Avhengig av stadium behandles ekinokokkose med anthelmintika (albendazol), aspirasjon (PAIR: punksjon, aspirasjon, instillasjon av alkohol, reaspirasjon) eller kirurgi med enten eksisjon av hele cysten eller partiell eksisjon dersom cysten er adherent til vitale organer ( $\underline{2}$, 3). Scolicidale midler (av scolex: bendelmarkens hode) dreper bendelmarker og brukes ofte ved reseksjon av parasittære cyster (4.). Det finnes flere typer scolicidale midler, som for eksempel hypertont saltvann, formalin, hydrogenperoksid, cetrimid og klorheksidin (44,5).

Pasienten ble vurdert av infeksjonsmedisiner, og det ble anbefalt kirurgisk cystereseksjon i tillegg til antiparasittcer behandling med albendazoltabletter $400 \mathrm{mg}$ morgen og kveld fra og med dagen før operasjonen. Ved intraoperativ ruptur av cyster ble det anbefalt skylling av bukhulen med $20 \%$ hypertont saltvann og i tillegg prazikvanteltabletter $30 \mathrm{mg} / \mathrm{kg}$ morgen og kveld for å redusere risikoen for tilbakefall.

To cyster var utilgjengelige for reseksjon uten omfattende organreseksjon. Disse ble først aspirert, deretter ble hypertont saltvann instillert før fenestrering og uthenting av dattercyster (figur 2). Under operasjonen rumperte to cyster spontant. Grunnet cysteruptur ble bukhulen avslutningsvis skylt med 2 liter hypertont saltvann i ti minutter. Saltvannet ble sugd ut, og bukhulen ble skylt i to runder med fysiologisk (o,9\%) saltvann. Pasienten var stabil under inngrepet, men var pressorkrevende. Operasjonen varte $i$ totalt 12 timer. 


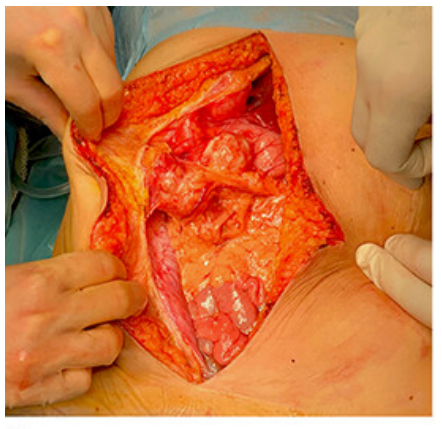

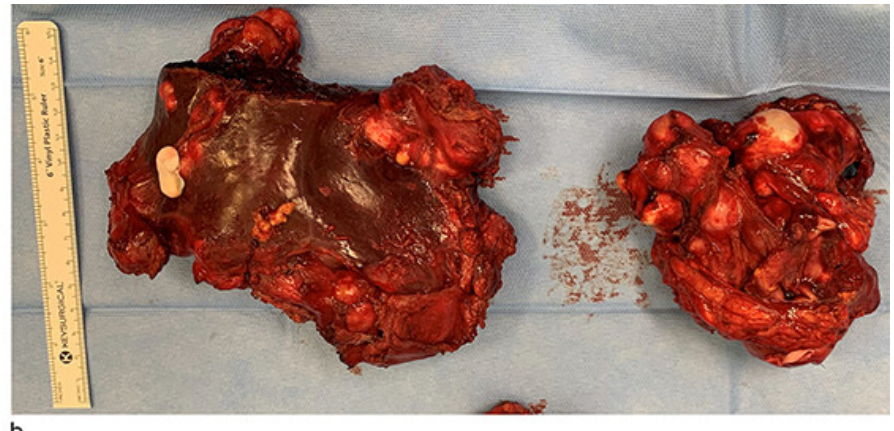

b

Figur 2 Bilder tatt under operasjon. a) bukvegg med adherente cyster, b)

operasjonspreparat: til venstre leverresektat med cyster, til høyre intraabdominale cyster.

Linjalen indikerer størrelsen $(15 \mathrm{~cm})$.

En halvtime etter ekstubering pustet pasienten selv, men hadde ikke våknet. Glasgow Coma Scale (GCS)-skår var 6, pasienten var motorisk urolig og hadde sidelike, små pupiller med usikker lysreaksjon. Hun var takykard med hjertefrekvens $150 \mathrm{slag} / \mathrm{min}$, hypotensiv med blodtrykk 8o/6o mm $\mathrm{Hg}$ og middelarterietrykk 6 o mm Hg under pågående infusjon av noradrenalin o,3 $\mu \mathrm{g} / \mathrm{kg} / \mathrm{min}$ og med 7 liter i positiv vaskebalanse. Arteriell blodgass viste metabolsk acidose og elektrolyttforstyrrelser med natrium $188 \mathrm{mmol} / \mathrm{L}$ (137-144), klorid $153 \mathrm{mmol} / \mathrm{L}$ (102-110), kalium 5,2 mmol/L (3,6-4,6), pH 7,19 (7,35-7,45), bikarbonat 14,3 mmol/L (22,0-26,o), Baseoverskudd-12 mmol/L (-3 til +3), laktat 2,7 mmol/L (o,5-2,5), blodsukker 7,3 mmol/L (referanseverdi fastende 4,2-6,3). Pasienten ble umiddelbart overflyttet til intensivavdeling.

Kvinnen hadde flere elektrolyttforstyrrelser, men hypernatremi var den mest alvorlige og potensielt dødelige. Hypernatremi skyldes vanligvis dehydrering med tap av vann uten samtidig tap av salter eller redusert vanninntak. Sjeldnere kan hypernatremi sees som følge av saltforgiftning. I dette tilfellet tror vi at pasientens hypernatremi skyldtes en

kombinasjon av økt absorpsjon av natrium i ferske store sårflater i buken og den osmotiske effekten av hypertont saltvann i bukhulen. Sistnevnte trekker vann ut av det intracellulære rom og bidrar dermed til et vanntap som ikke blir registrert. Dette kunne dels forklare pasientens hypovolemi og pressorkrevende hypotensjon, tross positiv væskebalanse. Klinisk manifesterer hypernatremi seg fra ingen symptomer til økt tørste og irritabilitet hos en våken pasient og til kramper, koma og død. Pasienten hadde ingen krampeanfall, men den observerte motoriske uroen kan sannsynligvis tilskrives hypernatremi. Alvorlig hypernatremi (>165 mmol/L) er uvanlig og har høy dødelighet $(\underline{6})$. Tilstanden krever intensiv behandling og tett monitorering. Behandlingen går ut på å identifisere og korrigere utløsende årsak og å fortynne blodet til man oppnår normale verdier.

På intensivavdelingen ble det umiddelbart startet infusjon med 5 \% glukose, først $200 \mathrm{~mL}$ bolus, deretter 8,6 mL/kg/time. Det ble også startet infusjon av slyngediuretika (furosemid $30 \mathrm{mg} / \mathrm{t} i$ 30 minutter, deretter $10 \mathrm{mg} / \mathrm{t}$ ) for å øke utskilling av natrium via nyrene. Natrium- og glukoseverdier ble kontrollert hver halvtime via arteriell blodgass. CT caput tatt tre timer etter at hypernatremien ble oppdaget, viste ikke tegn til cerebral blødning. Syv timer etter oppstart av glukoseinfusjon hadde pasienten natriumverdi på $160 \mathrm{mmol} / \mathrm{L}$ og plasma-glukose på $35 \mathrm{mmol} / \mathrm{L}$ (7,3 $\mathrm{mmol} / \mathrm{L}$ før oppstart av glukoseinfusjon, referanseverdi fastende 4,2-6,3 mmol/L). Hyperglykemien hadde ikke respondert på insulininfusjon (3o IE/time) eller gjentatte bolusdoser. Man valgte å pause glukoseinfusjonen til pasientens glukoseverdier var under kontroll. Fire timer senere hadde p-glukose sunket til 14,5 mmol/L samtidig som natrium igjen steg til $169 \mathrm{mmol} / \mathrm{L}$. Det ble da startet infusjon med $5 \%$ glukose $3 \mathrm{~mL} / \mathrm{kg} /$ time, som gradvis ble økt til $5 \mathrm{~mL} / \mathrm{kg} /$ time (figur 3 ). 


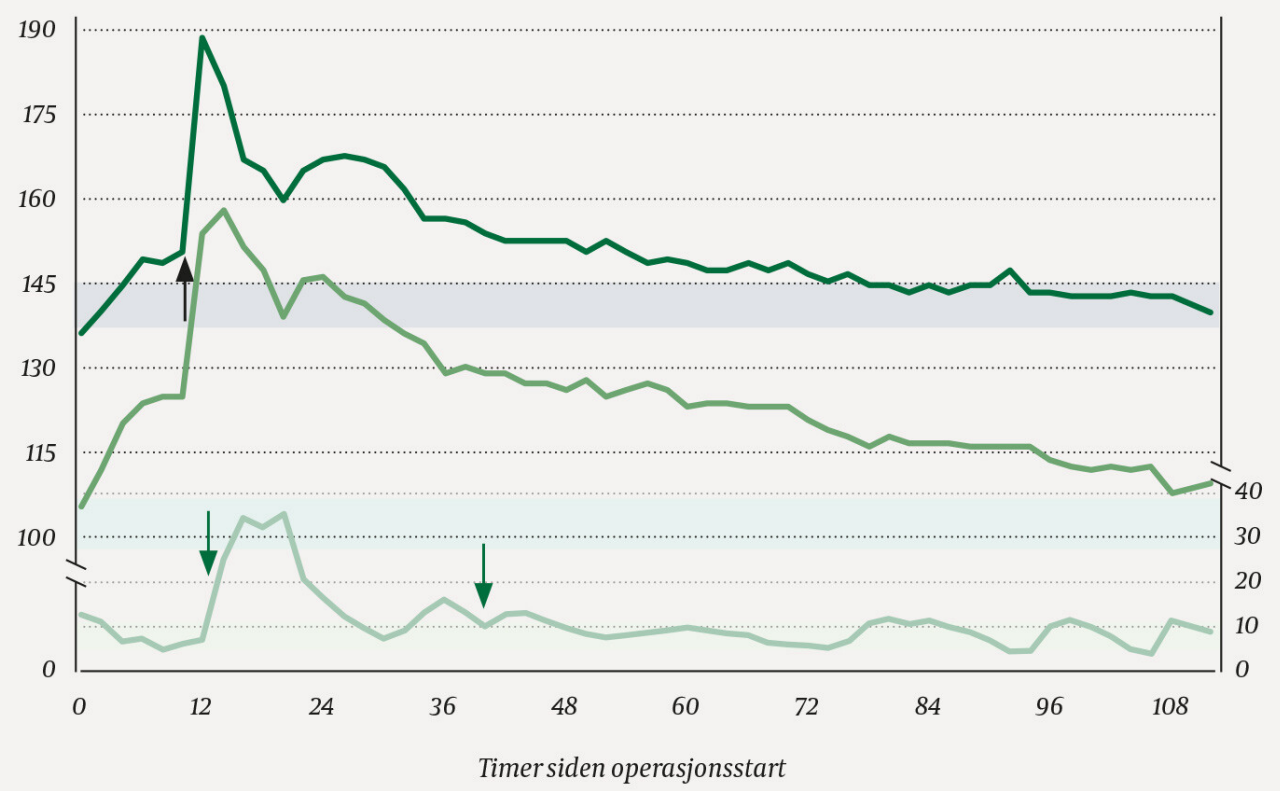

Figur 3 Grafen viser utviklingen av pasientens plasmaverdier av natrium (mørkegrønn linje), klorid (grønn linje) og glukose (lysegrønn linje). Referanseområder for de enkelte prøvene er markert med skraverte felter i henholdsvis grått, grønt og limegrønt (ikkefastende). Svart pil angir lavage av bukhulen med hypertont saltvann med 10 minutters varighet. Grønne piler angir start og stopp av 5 \% glukoseinfusjon.

Man skiller mellom akutt ( $<48$ timer) og kronisk hypernatremi. Dette har betydning for korreksjonshastighet. Overgangen fra akutt til kronisk skjer gradvis. Desto nærmere man kommer 48 timer etter utløsende årsak, jo større fare er det for utvikling av hjerneødem ved for rask korreksjon, da cellene inntar ny likevekt og dermed blir mer sårbare for svelling.

Dette tilfellet hadde en klar utløsende årsak og kjent starttidspunkt, ettersom pasienten utviklet akutt, alvorlig hypernatremi etter skylling av bukhulen med hypertont saltvann. Hypernatremi korrigeres med hypotone væsker, for eksempel vann (per os eller sonde) eller $5 \%$ glukose (infusjon), med $3-5 \mathrm{~mL} / \mathrm{kg} /$ time som anbefalt infusjonshastighet $(\underline{6}, 7$. .). Så høye doser medfører risiko for hyperglykemi, spesielt ved diabetes mellitus, som hos vår pasient. Vår pasient utviklet samtidig forbigående insulinresistens, som dels kan skyldes stressrespons etter langvarig kirurgi ( $\underline{8})$.

Retningslinjer for korreksjonshastighet av kronisk hypernatremi er maksimalt $10 \mathrm{mmol} / \mathrm{d} ø$ gn. Ved akutt oppstått hypernatremi er det risiko for hjerneblødning (9.). Vi valgte derfor å senke natrium raskt for å unngå et vedvarende drag på hjernens kar, samtidig som vi antok at det ennå ikke var skjedd endringer i antall osmoler i hjernecellene.

I løpet av de neste timene utviklet pasienten i tillegg til hypernatremi og hyperglykemi også hyperkloremi (155 mmol/L (101-110)), hypokalemi (3,1 mmol/L (3,5-4,4)), hypofosfatemi (o,2 mmol/L $(o, 8-1,4))$ og hypomagnesemi $(0,54 \mathrm{mmol} / \mathrm{L}(o, 71-0,94))$. Renalt tap på grunn av osmotisk diurese ved hyperglykemi og intracellulcer utveksling (shift) som følge av insulinbehandling kan ha bidratt til de øvrige elektrolyttforstyrrelsene, som ble korrigert med infusjon med kaliumklorid, kaliumdihydrogenfosfat og magnesiumsulfat. Foruten hypernatremi og hyperkloremi var elektrolyttforstyrrelsene normalisert i løpet av første postoperative døgn. Pasienten fikk 
kreatininstigning fra $50 \mu \mathrm{mol} / \mathrm{L}$ til $100 \mu \mathrm{mol} / \mathrm{L}$ (45-9o) og høy diurese opp mot 500-70o mL/t. Urinosmolaliteten som ble tatt etter at pasienten hadde fätt furosemidinfusjon, var $475 \mathrm{mosmol} / \mathrm{kg}$ (501200). I plasma var den $343 \mathrm{mosmol} / \mathrm{kg}(280-300)$.

Ved akutt nyresvikt bør dialyse vurderes og eventuelt startes opp så raskt som mulig. Vår pasient hadde en rask dobling av kreatininverdien, som skyldes akutt nyreskade, men hun hadde god diurese. Dialyse ble derfor ikke nødvendig. Pasientens høye diurese ble antatt å være forårsaket av furosemidinfusjonen sammen med osmotisk diurese på grunn av hyperglykemi. Sistnevnte fører til tap av elektrolyttfattig vann, som igjen motvirker reduksjonen av serum-natrium.

Ved nevrologisk tilsyn dagen etter operasjonen var pasienten våken og pustet selv. Hun beveget alle ekstremiteter og var motorisk urolig. Hun ga ikke adekvat kontakt, utover å åpne øynene på tiltale. GCS-skår var 10, pupillene var små, men lysreaktive. Plantarrefleksen var ikke invertert, mens øvrige reflekser var vanskelige å vurdere grunnet uro. Nevrolog konkluderte med sikker cerebral affeksjon, sannsynligvis utløst av alvorlig hypernatremi. Det ble anbefalt ny kontroll med CT eller MR caput for å utelukke hjerneødem eller blødning.

MR caput gir best vurdering av hjerneødem og annen cerebral patologi, men det krever en samarbeidsvillig pasient som kan ligge rolig i opptil 40 minutter. CT caput er tilstrekkelig til å kunne utelukke større patologi som blødning og hjerneødem.

Bruk av sedasjon for å få gjennomført CT caput-kontroll etter 12 timer ble diskutert. For å kunne overvåke pasientens bevissthetsnivå ble hun sedert med propofol i titrerte doser til hun var rolig, men fortsatt selvpustende. CT caput etter 12 timer var uten tegn til hjerneblødning eller-ødem. Det ble lagt ventrikkelsonde for administrering av vann og anthelmintika (albendazol $400 \mathrm{mg} \times 2 \mathrm{og}$ prazikvantel $30 \mathrm{mg} / \mathrm{kg} \times 2$ ).

Andre postoperative dag var GCS-skåren 11, og pasienten reagerte noe mer på tiltale.

Glukoseinfusjonen ble endret til $10 \%$, med en hastighet på o,75 $\mathrm{mL} / \mathrm{kg} /$ time. Natriumnivåene falt jevnt fra $154 \mathrm{mmol} / \mathrm{L}$ til $148 \mathrm{mmol} / \mathrm{L}$. Vi valgte å fortsette forsiktig korreksjon til normonatremi med en planlagt reduksjon på $5 \mathrm{mmol} /$ døgn.

Selv om pasienten fremdeles hadde lettgradig hypernatremi, valgte vi å trappe ned på korreksjonshastigheten for å redusere risiko for hjerneødem. Vi anså at pasientens hypernatremi på dette tidspunktet hadde vart så lenge at den måtte behandles som kronisk. Kontrollhyppighet av natrium ble redusert fra hver halvtime til annenhver time. Figur 3 viser utviklingen av pasientens natriumnivå.

Tredje postoperative dag våknet pasienten til. Hun var klar og orientert for tid, sted og situasjon, men hadde komplett amnesi fra hun ble lagt i narkose til den aktuelle dagen. Utover dette hadde hun ingen åpenbare nevrologiske sekveler. Pasienten var tørst og begynte forsiktig å spise og drikke. Hun var tungpustet, trengte 5 L oksygen på nesegrime og hadde reduserte lungelyder. Røntgen toraks viste pleuravceske bilateralt. Det ble gjort ultralydveiledet drenasje av $1600 \mathrm{~mL}$ pleuravceske. I samråd med nyrelege ble det startet vaskerestriksjon med maksimalt $500 \mathrm{~mL}$ per os per dag, og hun fikk bumetanid $3 \mathrm{mg} \times 2$ intravenøst.

Akutt alvorlig hypernatremi kan gi langtidssekveler (10 $)$. Vår pasient våknet tilsynelatende uskadd fra denne alvorlige komplikasjonen. Natriumnivåene til pasienten lå fremdeles over normalområdet, og på grunn av samtidige tegn på hypervolemi valgte man å legge til diuretika i behandlingen.

Neste dag var natriumnivået stabilt rundt 143-144 mmol/L, i øvre normalområde. Ventrikkelsonden ble seponert og pasienten overflyttet til sengepost, med kontroll av natriumnivå to ganger daglig. Pasienten var $i$ klinisk bedring, men fremdeles tungpustet og med behov for oksygen.

Kreatininverdien, som hadde vcert fallende siden andre postoperative dag, var normalisert. Femte postoperative dag ble glukoseinfusjonen seponert, og pasienten fikk drikke fritt. Natriumnivået falt ytterligere til $140 \mathrm{mmol} / \mathrm{L}$. CT toraks og abdomen som ble tatt for å utelukke lungeemboli eller intraabdominal årsak til vedvarende dyspné, viste pleuravceske og atelektaser, men ingen lungeemboli. I abdomen var det uttalt ascites og dilaterte tynntarmsslynger uten tegn til mekanisk ileus. 
Dyspné og nedsatt oksygenmetning postoperativt er vanlige symptomer på atelektaser, pneumoni og lungeembolisme, som ikke er uvanlige komplikasjoner etter langvarig kirurgi. Pleuravæske og ascites forklares av de store væskeskiftene pasienten hadde i løpet av 3-5 dager. På sengepost fikk pasienten lungefysioterapi og ble utstyrt med PEP-fløyte for å motvirke lungekomplikasjoner. Funn av dilaterte tynntarmsslynger var forenlig med paralytisk ileus, som er svært vanlig etter manipulasjon av tarmene. Ofte varer disse 37 dager etter operasjon. Pasientens tarmfunksjon kom imidlertid raskt i gang etter oppvåkning.

Syvende postoperative dag ble pasienten skrevet ut til lokalsykehus for videre mobilisering. Ved kontroller postoperativt har hun vart i god allmenntilstand, men har hatt hårtap, som er en kjent bivirkning av albendazol. CT abdomen seks måneder etter operasjonen viste upåfallende forhold $i$ abdomen. Det er planlagt behandling med albendazol i til sammen 12 måneder og ny CT-kontroll ved avslutning av medikamentbehandlingen.

\section{Diskusjon}

Kasuistikken illustrerer en komplikasjon med potensielt dødelig utfall hos en ung pasient etter et planlagt kirurgisk inngrep. Hendelsen viser kompleksiteten og alvorligheten av akutt hypernatremi og betydningen av kjennskap til iatrogene, akutte elektrolyttforstyrrelser og korreksjon av disse.

Levercyster er en svært vanlig tilstand som ofte påvises som et bifunn ved radiologiske undersøkelser gjort på annen indikasjon. De fleste cyster gir ingen symptomer, er helt ufarlige og trenger ingen oppfølging eller behandling. Kirurgisk behandling kan være aktuelt ved levercyster som gir pasienten smerter, kolestase eller symptomer på grunn av trykk på naboorganer. Ekinokokkcyster kan se ut som simple cyster, og anamnesen bør derfor inneholde en grundig reiseanamnese, nærkontakt med dyr og inntak av ubehandlede fødemidler, som sopp, bær, salater og grønnsaker som kan være kontaminert av infiserte hundedyr. Av den grunn bør ekinokokkserologi vurderes før kirurgisk behandling av antatt simple levercyster, da aksidentell utsæd av larver i bukhulen, slik som hos vår pasient, kan få alvorlige følger med risiko for utvikling av cyster i hele bukhulen.

Serologisk test er nå blitt tilgjengelig ved referanselaboratoriet for parasittologi ved Universitetssykehuset Nord-Norge. Ved negativ serologi, usikker diagnose og klinisk relevans, kan cysten punkteres og cysteinnhold sendes til mikrobiologisk undersøkelse. Hvis det hos vår pasient hadde blitt påvist ekinokokksykdom ved histologisk undersøkelse av cysteveggen etter første operasjon, ville det ha vært aktuelt å behandle pasienten med albendazol $400 \mathrm{mg} \times 2$ i 12 måneder samt prazikvantel $30 \mathrm{mg} / \mathrm{kg} \times 2$ i fire uker. Dette kunne ha begrenset sykdomsutbredelsen i abdomen og $\mathrm{i}$ beste fall hindret en ny, komplisert og langvarig operasjon.

Ruptur av ekinokokkcyster under operasjonen medførte søl av cysteinnhold med larver. Dette kan føre til tilbakefall av ekinokokkcyster og var årsaken til at vi brukte hypertont saltvann for skylling av bukhulen. Man kan i ettertid diskutere om man på forhånd burde ha forutsett risikoen for hypernatremi, og dermed kunne ha lagt en plan for å monitorere natriumnivåene med hyppige elektrolyttanalyser under og etter lavage av bukhulen, som ble utført mot slutten av det 12 timer lange inngrepet.

Natrium er det dominerende kationet i plasma og ekstracellulærvæske. Under fysiologiske forhold er natrium ansvarlig for osmolaritet, elektrolyttbalanse, væske- og blodvolum. Ved hypernatremi skrumper cellene, da økt osmotisk trykk ekstracellulært trekker vann ut av cellen. Cerebralt kan skrumpningen føre til hjerneblødning som følge av strekk og ruptur av brovener, eller fokale intracerebrale og subaraknoidale blødninger.

Tørste er et vanlig symptom på hypernatremi og er ved fysiologiske forhold den viktigste og som oftest en tilstrekkelig refleks for å forhindre hypernatremi. Kasuistikken illustrerer hvor sårbar en bevisstløs pasient er for væske- og elektrolyttforstyrrelser og hvor vanskelig 
det kan være å fange det opp.

Hypertont saltvann $(20 \% \mathrm{NaCl})$ er et etablert scolicidalt middel ved behandling av ekinokokkcyster, primært for instillasjon i cyster, men også til skylling av bukhulen ved cysteruptur (4,.5). Iatrogen hypernatremi med fatalt utfall er tidligere beskrevet etter behandling med hypertont saltvann (11-13). Det er beskrevet andre scolicidale midler, som cetrimid, men de er ikke godkjent for denne indikasjonen i Norge.

Pasienten utviklet hypernatremi, som var en alvorlig og potensielt dødelig følge av behandlingen for ekstensiv cystisk ekinokokksykdom. I vårt tilfelle ble hypernatremien oppdaget raskt, og effektiv behandling ble iverksatt så tidlig at risikoen for komplikasjoner ble minimalisert. Hendelsen ble meldt i sykehusets avvikssystem samt til Statens helsetilsyn under innleggelsen. Rutine for kirurgisk behandling av ekinokokksykdom ved Oslo universitetssykehus er nå blitt endret, og det anbefales årvåkenhet ved bruk av hypertont saltvann i bukhulen og på sårflatene på grunn av risiko for hypernatremi.

Pasienten har gitt samtykke til at artikkelen blir publisert. Artikkelen er fagfellevurdert.

\section{LITTERATUR}

1. Pomianowska E, Bjørnbeth BA, Rojahn AE et al. Levercyste fra Østen. Tidsskr Nor Legeforen 2014; 134: 716. [PubMed][CrossRef]

2. Folkehelseinstituttet. Ekinokokkose - veileder for helsepersonell.

https://www.fhi.no/nettpub/smittevernveilederen/sykdommer-a-a/ekinokokkose---veileder-forhelsepe/ Lest 9.2.2021.

3. Gomez I Gavara C, López-Andújar R, Belda Ibáñez T et al. Review of the treatment of liver hydatid cysts. World J Gastroenterol 2015; 21: 124-31. [PubMed][CrossRef]

4. Besim H, Karayalçin K, Hamamci O et al. Scolicidal agents in hydatid cyst surgery. HPB Surg 1998; 10:347-51. [PubMed][CrossRef]

5. Sharafi SM, Sefiddashti RR, Sanei B et al. Scolicidal agents for protoscolices of Echinococcus granulosus hydatid cyst: Review of literature. J Res Med Sci 2017; 22: 92. [PubMed][CrossRef]

6. Kim SW. Hypernatemia : successful treatment. Electrolyte Blood Press 20o6; 4: 66-71. [PubMed] [CrossRef]

7. Sterns RH, Hoorn EJ. Treatment of hypernatremia in adults. https://www.uptodate.com/contents/treatment-of-hypernatremia-in-adults Lest 9.2.2021.

8. Thorell A, Nygren J, Ljungqvist O. Insulin resistance: a marker of surgical stress. Curr Opin Clin Nutr Metab Care 1999; 2: 69-78. [PubMed][CrossRef]

9. Ingvaldsen B. Væske, elektrolytter, blodgasser og infusjonsterapi. 6. utg. Oslo: Baard Ingvaldsen, 2019.

10. Engjom T, Kildahl-Andersen O. En 83 år gammel bevisstløs kvinne med hypernatremi. Tidsskr Nor Laegeforen 2008; 128:316-7. [PubMed]

11. Krige JE, Millar AJ, Rode $\mathrm{H}$ et al. Fatal hypernatraemia after hypertonic saline irrigation of hepatic hydatid cysts. Pediatr Surg Int 2002; 18: 64-5. [PubMed][CrossRef]

12. Zeng R, Wu R, Lv Q et al. The association of hypernatremia and hypertonic saline irrigation in hepatic hydatid cysts: A case report and retrospective study. Medicine (Baltimore) 2017; 96: e7889. [PubMed][CrossRef]

13. Arambewela MH, Somasundaram NP, Garusinghe C. Extreme hypernatremia as a probable cause of fatal arrhythmia: a case report. J Med Case Reports 2016; 10: 272. [PubMed][CrossRef]

Publisert: 22. oktober 2021. Tidsskr Nor Legeforen. DOI: 10.4045/tidsskr.21.0184

Mottatt 5.3.2021, første revisjon innsendt 6.6.2021, godkjent 27.6.2021.

Publisert under åpen tilgang CC BY-ND. Lastet ned fra tidsskriftet.no 26. april 2023. 